\title{
ANAYSING THE IMPACTS OF FREE CASH FLOW AND AGENCY COST TOWARDS FIRM PERFORMANCE IN THE PUBLIC LISTED COMPANIES IN MALAYSIA
}

\author{
Noraina Mazuin Sapuan 1,*, Norwazli Abdul Wahab ${ }^{1, *}$, Muhammad Ashraf Fauzi ${ }^{1}$, Akrom Omonov ${ }^{2}$ \\ 1 Faculty of Industrial Management, Universiti Malaysia Pahang, 26300 Kuantan, Pahang, Malaysia. \\ 2 Department of Banking, Tashkent Institute of Finance, Amir Temur Street, Tashkent, Uzbekistan
}

\begin{abstract}
This study intended to examine the relationship between free cash flow and agency costs towards firm performance based on the data from 350 public listed companies in Malaysia. The data was collected from year 2005 to 2015 . There is a need to re-examine the free cash flow hypothesis and the agency theory based on Malaysian data as the results from previous studies shown a mix results. The findings shown free cash flow is significantly giving positive impact on firm performance. This result is contradict to free cash flow hypothesis, but it can occur due to, when the availability of investments opportunities that can be generated when firm more free cash flow that later able to increase firm performance. Meanwhile, total asset turnover has a positive impact on return on asset. However, the operating expenses ratio demonstrates that the operating expenses ratio has a negative impact on return on asset. The mix findings of agency cost are supported by previous studies.
\end{abstract}

ARTICLE HISTORY

Received: 2-9-2021

Revised: 26-9-2021

Accepted: $29-11-2021$

\section{KEYWORDS}

Free cash flow

Agency cost

Firm performance

Malaysia

\section{INTRODUCTION}

The major financial scandals such as Enron Corporation, WorldCom, and Waste Management called into doubt the accuracy and trustworthiness of accounting data. This has led to the establishment and integrity of the governance structure in providing information openness, protecting investors from manipulation, and generating strong economic certainties and the company's actual performance. For instance, Felda Global Venture suffered losses of roughly RM57 million in 2017 due to anomalous stock in the Turkish Unit. The deception comprises the management of stock data as well as the fabrication of board member signatures. The accounting or finance department does not thoroughly review their financial statement, resulting in deception in their company's financial report. As a result, the free cash flow has received more attention as a statistic that is less manipulated by managers.

According to Jensen (1986), the occurrence of free cash flows in the company produces conflicts among partners because each one of them attempts to use these cash flows to maintain its usefulness or to promote his interests. Once a company has a high FCF level but is not in a stage where it may profit from significant growth potential, there is a concern. Johnson and Meckling (1976) added, because the separation of proprietorship, control, and agency costs that emerge from shareholders' inability to monitor managers' treatment, resulted in pressures and conflicts between shareholders and managers.

The core premise of agency theory is that each actor seeks to maximize his self-interest, which leads to the emergence of conflicts (Ross, 1977). The assumption that financial markets are perfect is excluded under these circumstances. Irregularities of evidence and conflicts of interest will determine these. Numerous studies have attempted to assess agency costs and examine their impact on both the cost of capital and company value (Li et al, 2021; Choudhary, 2021; Pahii and Yadav, 2021). In the context of agency theory, leverage is seen as a cost-effective way to resolve conflicts of interest that can arise between shareholders and managers. Unlike Modigliani and Miller's (1958) thesis, which linked the capital structure solely to a cash-flow model, leverage's importance is linked to creditors' ability to exercise control.

Free cash flow is important because it allows the company to pursue opportunities that cultivate stockholder holdings. Nevertheless, in the connection between business management and investors, both sides search for the greatest total of profit for themselves, resulting in divergent viewpoints on the best strategy for the company. The conflict of interest between management and stockholders increases when a company generates a high amount of free cash flows. As a result, the agency dilemma is encouraging the agent to make judgments that maximize the assets of the owners.

Thus, this research intends to examine the impact of free cash flow and agency cost on firm performance among Malaysian public listed companies. This study may provide answers to many questions asked by interested individuals or institutes. This research will look at how these characteristics influence firm performance and how investors may use this information to make the best investment decisions possible. This research could provide answers to a variety of concerns posed by individuals or organizations. 


\section{LITERATURE REVIEW}

\section{Free Cash Flow (FCF)}

Free cash flow (FCF) is a measure of a company's ability to produce revenue. Jensen (1986) pioneered the ideas of free cash flow (FCF) and idle cash flow. Jensen (1986) defined free cash flow as "cash flow above the required amount to fund all projects that have positive net present value (NPV)". Perhaps, managers are more likely to expand the company beyond its optimal size by taking on new initiatives, although the net present value is negative. To strengthen their position and reputation, it is very important to ensure they have good cash control. Furthermore, companies with excess cash flows but limited growth prospects will rely more on debt financing (Jensen, 1986).

However, these principles may cause conflicts between the interests of management and shareholders, resulting in poor performance. This will have an impact on dividend payout policy, as the managers seek to raise dividends rather than make investments with returns below the cost of capital. This is confirmed by Bhundia (2012), who stated that it is not required to spend all of the operational cash flow to purchase new assets for the company to maintain its existing activity; but a portion of it should be disseminated as dividends as well.

\section{Agency Cost}

Agency costs are considered sorts of internally induced costs to the company and have resulted in an insufficiency of the manager-principal relationship. Conflict of interest arises when a company's manager or executives act in their own best interests at the expense of the company's primary or shareholders. They may embezzle corporate funds or falsify financial statements for personal gain. According to the agency theory, when managers' aims vary from those of the shareholders and the firm's governing policy is ineffective, managers will try to achieve their aims, which may or may not be aligned with those of the shareholders (Griffin et al., 2010). These decisions can affect the performance of firms (Sapuan et al., 2020; Ahmed et al, 2020; Sapuan and Mohd Zeni, 2021; Gani et al, 2021;

There are three types of agency costs described by Jensen and Meckling (1976); monitoring costs, bonding costs, and residual loss. Monitoring expenses are referred to as agency costs. These costs are incurred in hiring auditors in a firm in support of the shareholders to verify and control the manager's natural process to check activities that raise shareholder value. The bonding expenses include a bond covenant, which is an agreement that prevents the company from taking certain actions, such as restrictive dividend payments. However, a residual loss is the expenses incurred as a result of conflicting shareholder and manager interests.

According to Gul et al. (2012) when the company has a greater number of independent directors will have lesser agency costs because an independent director has a substantial influence on the company performance. When there is a smaller board member and high independent director, the agency cost will be decreased, and the company can perform well. This is consistent with the finding from Choudhary (2021), firms with a good governance system, a small board size, and a greater number of non-executive directors, can outperform in resolving agency conflicts. Meanwhile, Pahii and Yadav (2021) found evidence that external corporate governance and dividend policy are substitutes, and higher agency costs and higher internal governance strengthen this relationship. The outcomes of this study can help the managers to more precisely take dividend decisions by looking at the competition level in the market.

\section{Free cash flow, Agency Cost and Firm Performance}

There are many empirical investigations have been conducted and mostly in the developed countries (Antoniadis et al., 2008; Migunyi, Zanjirder and Gasemy, 2013; Wambua, 2013; Nobance, Ellili and Abraham, 2017; Hau, 2017; Kadiugloe et al,2017; Abdullah et al, 2019). According to Jensen's (1986) theory, having a big free cash flow might lead to a conflict within the company, such as between the interest manager and the shareholder, which will harm the company's performance.

Other studies use return on assets (ROA) and return on equity (ROE) in addition to Tobin's Q to measure the firm performance (Omonov et al, 2021; Wong et al., 2019; Ghanvari et.al., 2015; Velnampy and Kajanathan, 2013; Hydari et al., 2014); Abughniem et al., 2020). For over ten years, Liman and Mohammed (2018) have studied the impact of Operating Cash Flow and Corporate Financial Performance in Nigeria (2005 to 2014). The results show a positive but minor relationship between Cash Flow from Operating Activities (CFO) and financial success as measured by ROA, but a positive and substantial relationship when financial performance is measured by ROE of Nigeria's listed conglomerate businesses. Abughniem et al., 2020 used panel data regression to show that free cash flow for Amman Stock Exchange companies (2010 to 2015) affected solely the return on assets and market value per share.

According to Hau (2017), free cash flow control is usually one of the biggest challenges in organizations, since if a firm does not have an investment, retaining more cash will not help to increase firm performance. Furthermore, several proxy variables are recommended to measure agency cost which are total asset turnover, operating expense to sales ratio, administrative expense, earning volatility, advertising and $R \& D$ expense to sales ratio, and floatation cost. Total asset turnover and operational expenses are the greatest indicators to use.

Based on the study by Kadioglu et al. (2017), the Turkish capital market has a negative link between free cash flow, dividend payouts, and corporate performance (2009-2015) measured by Tobin's Q. This is supported by Wen (2017) examined the conflict between firms and free cash flow and company performance using 46,247 firm data from the year 2006. The findings demonstrate that organizations with free cash flow perform worse in terms of sales growth than those without it. Other research has discovered a negative link between free cash flow and performance includes Hwang et al., 
(2013); John et al., (2015), Labhane and Mahakud (2016), Byrd (2010), Wang (2010), Brush et al. (2000) and Abughniema et al. (2020).

However, findings for a period of four years by Lachheb and Slim (2017) indicate a positive relationship between free cash flows, operating performance, and company among French companies listed on Euronext (2003-2007). In addition, according to Sitthipongpanich (2017), having family owners reduces the sensitivity of investment and cash flow. Lower dividend distributions from large management shareholdings enhanced free cash flow.

Furthermore, Nuhu et al. (2020) looked at the influence of agency expenses on the financial performance of Nigerian consumer products companies from 2007 to 2016. The inverse association between agency costs and financial performance is revealed by a panel data regression, demonstrating that agency expenses will lead to a drop in financial performance.

Many earlier research, in instance, have included the assumption of free cash flow and interpreted their findings using the Agency theory. Based on the above literature findings, the current study proposes the following hypotheses:

H1: There is a relationship between free cash flow towards firm performance.

$\mathrm{H} 2$ : There is a relationship between free agency costs towards firm performance.

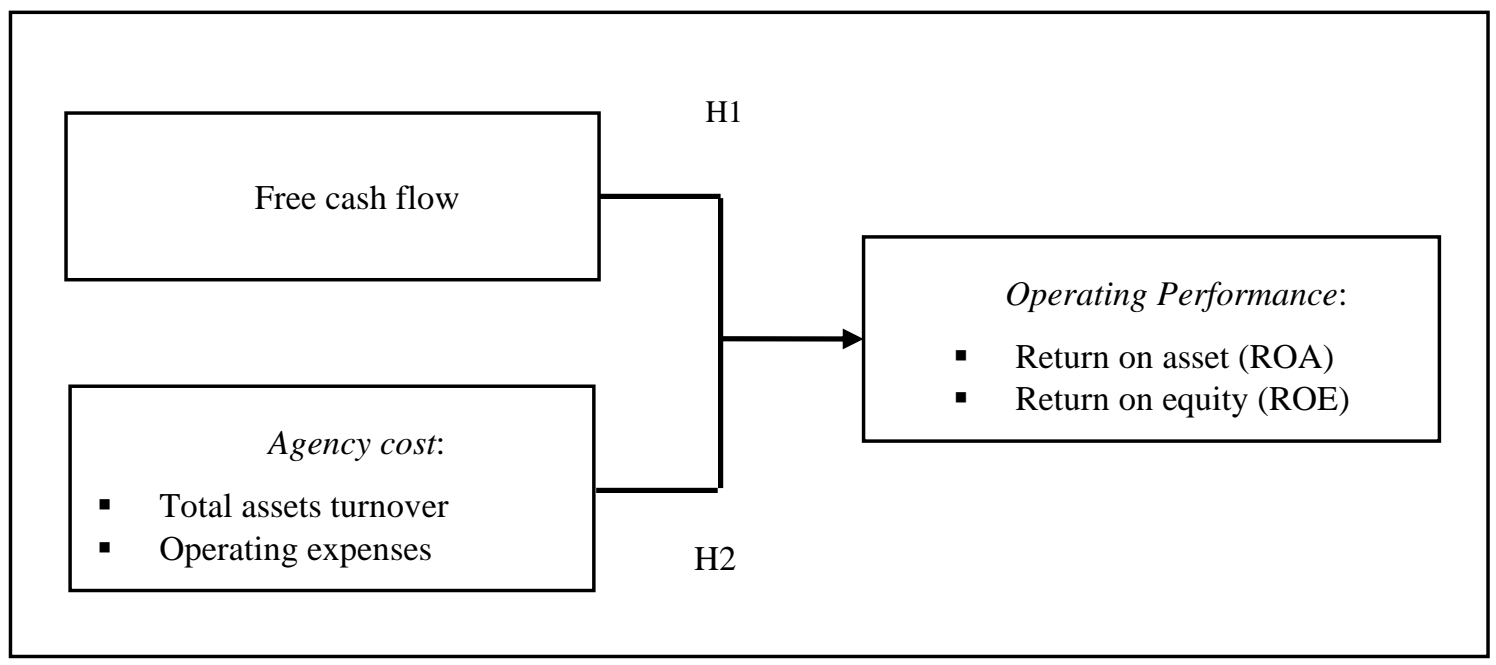

Figure 1 Conceptual Framework

\section{RESEARCH METHODOLOGY}

\section{Data}

The data of this study is based on 350 companies or representing $44 \%$ of the total number of companies on Bursa Malaysia Main Board. The data was collected from the year 2005 to 2015. This data was collected from the Thompson Reuter database. The time frame was selected due to the consideration of the pre-financial crisis in 2007 and the postfinancial crisis that give a huge impact on the performance of the stock market in Malaysia.

\section{Empirical Models}

In this study, we have two dependent variables namely return on asset (ROA), and return on equity (ROE). Meanwhile, two independent variables where are free cash flow and agency cost. For the free cash flow, we use formula cash flow from operating activities minus capital expenditure while for agency cost, we will use total asset turnover and operating expenses ratio. Based on previous empirical studies, we propose the empirical model as follows:

$\mathrm{ROA}_{\mathrm{it}}=\mathrm{B}_{0}+\mathrm{B}_{1} \mathrm{FCF}_{\mathrm{it}}+\mathrm{B}_{2} \mathrm{TAT}_{\mathrm{it}}+\mathrm{B}_{3} \mathrm{OER}_{\mathrm{it}}+\varepsilon$

ROEit $=\mathrm{B}_{0}+\mathrm{B}_{1} \mathrm{FCF}_{\mathrm{it}}+\mathrm{B}_{2} \mathrm{TAT}_{\text {it }}+\mathrm{B}_{3} \mathrm{OER}_{\mathrm{it}}+\varepsilon$

Where ROA is the return on assets; ROE is the return of equity; FCF is a free cash flow; OER is an operating expenses ratio and TAT is a total asset turnover.

Table 1: List of Variables and Formulas

\section{ITEMS / FORMULA}

\section{Dependent Variable}

Firm Performance:

Return on assets $($ ROA $)=$ Net profit After Tax $/$ Total Asset

Return of equity $(\mathrm{ROE})=$ Net income / Shareholder equity 


\section{Independent Variables}

Free cash flow $=$ Cash flow operating activities - capital expenditure

Agency Cost:

Total asset turnover $=$ Sales $/$ asset

Operating expenses ratio $=$ Operating/ sales

Return on assets is an indicator to identify how profitable a company is relative to its total assets. Return on asset gives an idea as to how efficient management is at using its assets to generate earnings. Meanwhile, return on equity is the amount of net income returned as a percentage of shareholder equity. Return on equity is measured by a corporation's profitability by revealing how much profit a company produces with the money shareholders have invested.

Free cash flow represents the ability of company cash to generate after spending the money required to maintain or expand its asset base. Total asset turnover is a ratio of the value company sales or revenue generated relative to the value of its assets. It is often can be used as an indicator of the efficiency in which a company is deploying its assets in generating revenue. The operating expense ratio is to measure what it costs to operate the property compared to the income that the property brings in. The operating expenses ratio can be calculated by dividing property operating expenses by gross income. This category shows the non-essential expenses incurred to generate sales. This ratio is directly related to agency costs. A high value for this ratio indicates that a firm's agency costs are high. (Chaudhary, 2021).

\section{FINDINGS AND DISCUSSION}

The descriptive statistic in Table 2 showed the values of minimum, maximum, and mean of the data. We used data from 350 companies public listed companies in Malaysia from various sectors. Return on asset (ROA) and return on equity (ROE) are the dependent variables while free cash flow (FCF), total asset turnover (TAT), and operating expenses ratio (OER) are the independent variables. As we can see from these figures, the minimum value of our data for return on asset, return on equity, and operating expenses ratio were negative. For total asset turnover, the minimum number is 0.00 , while for the free cash is 2.30 The maximum value for free cash flow is the highest with the value of 15.8509 , followed by return on equity is 15.2300 , return on asset which is 10.4653 , operating expenses ratio is 5.3257 and total asset turnover is 5.0738 .

Table 2: Descriptive Statistics of Variables

\begin{tabular}{lllll}
\hline Variable & Mean & Std. Dev. & Min & Max \\
\hline ROA & 1.3850 & 1.0013 & -4.6052 & 10.4653 \\
ROE & 1.6750 & 1.1569 & -4.6052 & 15.2300 \\
FCF & 6.9558 & 3.9218 & 2.3000 & 15.8509 \\
OER & 0.6900 & 0.5360 & -0.0034 & 5.3257 \\
TAT & 0.7346 & 0.5555 & 0.0000 & 5.0738 \\
\hline
\end{tabular}

Table 3 indicated the test of static panel regression. It starts with the analysis using Pooled OLS approach. This test ignored the panel nature of the data, and we assume both the intercept and the slope are the same across companies and time. The second approach i.e. Fixed Effect and the third approach i.e. Random Effect allows for unobserved heterogeneity represented by each company where each company has its individual intercepts while restricting the slopes to be homogenous.

Based on the results in Table 3, all variables in Model 1 and Model 2 based on Pooled OLS, FE 2-way, and random effect are significant and have a positive relationship except for operating expenses ratio (OER) with the firm performance namely ROA and ROE as dependant variables in all type of approaches. The operating expenses ratio (OER) showed a negative and significant relationship for both models at a $99 \%$ significant level in all three tests. The $\mathrm{R}^{2}$ shows the goodness of fit of each model, i.e. between 0.35 to 0.37 . Therefore, it is indicated that in all the tests, every model had between $35 \%$ to $37 \%$ variations in firm performance (ROA and ROE) can be explained by the independent variables, respectively.

Meanwhile, the $F$-test represents the test for the overall fitness of the model and the result implies that the null hypothesis is to be rejected. This suggests that at least one or more of the independent variables had influenced the dependent variable, firm performance. Following the rejection of the null hypothesis in the $F$-test, the individual coefficient of the estimated model was then tested. The $t$-test on each variable suggests that FCF, OER, and TAT are significant at $1 \%$ levels in Model 1 and 2 for all the tests, except for Model 2 under 2-way fixed effect FCF gives a positive impact towards ROE at $5 \%$ significant level.

The selection of the best estimation model was based on the Breusch-Pagan and Hausman test. To treat the groupspecific effects, this study will perform GLS with fixed effects and GLS with random effects regressions. Meanwhile, The Hausman test will be used to test the correct model assuming that the individual effects are uncorrelated with the other regressors in the model. The results of the Breusch-Pagan in Table s3hows that for all models, GLS with random effect is better than GLS with pooled least square at $1 \%$ significance level for all the models. This result indicates that there are group-specific effects in the data. The Hausman test also indicates that the null hypothesis of the lack of 
association between the individual effects and the explanatory variables was not accepted and the GLS estimator of the fixed effect was inconsistent.

The Hausman test results, as shown in Table 3, demonstrate that the fixed effect GLS results describe better than the random effects for both models. The findings of the Hausman test indicate that the null hypothesis is rejected and the alternative hypothesis of fixed effect GLS is accepted. This indicates the estimation differences of the variations of the variables are not found between groups and rely completely on variation within groups.

Table 3: Results of Pooled OLS, Fixed-Effect and Random-Effect GLS Regression Estimation for Growth

\begin{tabular}{|c|c|c|c|c|c|c|}
\hline & \multicolumn{2}{|c|}{ Pooled OLS } & \multicolumn{2}{|c|}{$\begin{array}{l}\text { GLS with 2-Way Fixed } \\
\text { Effect }\end{array}$} & \multicolumn{2}{|c|}{$\begin{array}{l}\text { GLS with Random } \\
\text { Effect }\end{array}$} \\
\hline & Model 1 & Model 2 & Model 1 & Model 2 & Model 1 & Model 2 \\
\hline Constant & $\begin{array}{l}0.8474 * * * \\
(26.77)\end{array}$ & $1.0991 * * *$ & $0.8752 * * *$ & $\begin{array}{l}1.1559 * * * \\
(1606)\end{array}$ & $\begin{array}{l}0.8935 * * * \\
(2260)\end{array}$ & $1.1382 * * *$ \\
\hline FCF & $\begin{array}{l}0.0307 * * * \\
(8.54)\end{array}$ & $\begin{array}{l}0.0255^{* * * *} \\
(6.12)\end{array}$ & $\begin{array}{l}0.0180 * * * \\
(4.78)\end{array}$ & $\begin{array}{l}0.0135 * * \\
(3.09)\end{array}$ & $\begin{array}{l}0.0241 * * * \\
(6.74)\end{array}$ & $\begin{array}{l}0.0193 * * * \\
(4.67)\end{array}$ \\
\hline OER & - & - & - & $-5.4814 * * *$ & - & $-6.4712 * * *$ \\
\hline TAT & $\begin{array}{l}6.2561 * * * \\
37.36) \\
\quad 6.3168 * * * \\
\quad(38.92)\end{array}$ & $\begin{array}{l}7.3820 * * * \\
(-38.15) \\
7.4766 * * * \\
(39.87)\end{array}$ & $\begin{array}{l}4.4186 * * * \\
21.00) \\
\quad 4.6483 * * * \\
\quad(22.75)\end{array}$ & $\begin{array}{l}(-22.46) \\
5.7645^{* * * *} \\
(24.33)\end{array}$ & $\begin{array}{l}5.3914 * * * \\
(-29.33) \\
5.5052 * * * \\
(30.93)\end{array}$ & $\begin{array}{l}(-30.42) \\
6.6265 * * * \\
(32.17)\end{array}$ \\
\hline $\mathrm{N}$ & 3509 & 3509 & 3509 & 3509 & 3509 & 3509 \\
\hline $\mathrm{R}^{2}$ & 0.3693 & 0.3693 & 0.3556 & 0.3565 & 0.3678 & 0.3678 \\
\hline $\mathrm{F}$ & 684.04 & 683.93 & 47.66 & 51.51 & 1167.62 & 1205.52 \\
\hline $\begin{array}{l}\text { Prob. } \\
\text { Breusch- }\end{array}$ & 0.00 & 0.00 & 0.00 & 0.00 & 0.00 & 0.00 \\
\hline Pagan test & & & $477.49 * * *$ & $482.49 * * *$ & & \\
\hline $\begin{array}{l}\text { Hausman } \\
\text { test }\end{array}$ & & & & & $88.13 * * *$ & $68.32 * * *$ \\
\hline
\end{tabular}

From the findings in Table 3, we can conclude that this study is not in line with the free cash flows hypothesis but there are mixed results to support the agency theory hypothesis. According to the free cash flows and agency costs hypothesis, free cash flows and agency costs harmed firm performance.

In this study, free cash flow has a significant positive impact on asset return. Our findings are supported by Hau (2017), who claims that when a firm has investment opportunities, free cash flow can significantly improve firm performance. This is also consistent with the study from Wang (2010) whereby there is a lack of evidence supporting the free cash flows hypothesis, where free cash flows could reduce for firms with investment opportunities which would generate more values for the firm. Therefore, free cash flows have a positive impact on firm performance especially for firms involved in merger activities (Gregory's, 2005). Moreover, Szewczyk et al. (1996) and Chang et al. (2007) concluded that investors prefer firms with excess cash flows.

For the agency cost, total asset turnover has a positive impact on return on assets and is significant at the $1 \%$ level. This is supported by the author Khidmat and Rehman (2014), who stated that the company can generate sales from its assets, which will result in increased firm performance. Meanwhile, the operating expenses ratio demonstrates that the operating expenses ratio has a negative impact on return on assets and is significant at level 1\%. This is also supported by Khidmat and Rehman (2014), who states that when the cost of operating property is high, the firm's performance suffers.

\section{CONCLUSION}

Free cash flow is essential in the company's operation as it indicates the capability of this company to reinvest the cash, make acquisitions, pay the dividend, buy back shares and pay the debt. Without free cash flow, the company needs to borrow loans from other institutions. Free cash flow is also important as it allows firms to chase opportunities for new investment and at the same time increase stockholders' asset. Hence, free cash flow is significantly giving a positive impact on firm performance. Our results are supported by a previous study by Hau (2017) which indicates that when a firm has investments opportunities, the free cash flow may significantly increase firm performance. This finding is also in line with the study by Wang (2010) and Gregory (2005) where free cash flows could render a firm with investment 
opportunities that would generate more value for the firm. Meanwhile, for the agency cost, total asset turnover has a positive impact on return on asset and is significant at level 1 percent. This is supported by Khidmat and Rehman (2014) which stated that the company is able to generate sales from its asset and increase firm performance. On the other hand, the second variable as a proxy of the agency cost namely operating expenses ratio has a significant negative impact on ROA and ROE at $1 \%$ and 5\% significant levels. This result is also in line with Khidmat and Rehman (2014) when operating expenditures of doing business involve high cost, it will decrease the firm performance. Our findings are able to benefit several areas that are concerned by investors and shareholders in understanding what happened to the company with excess free cash flow and how it gives impacts to the existence of agency cost. Without proper monitoring of the agency cost, shareholders can only be faced with big losses in their investment.

However, there are some limitation in this study especially in terms of the data and variables used for the analysis. It is recommended for the future study, the data period should be extended in order to get more sufficient results. The used of more variables as proxy for the dependent variable such as net profit margin and tobin-q. Moreover, it is suggested that future study should also examine the comparison between companies that have lots of investment and companies with less opportunities in investment because the impact of free cash flow on firm performance different between firms with and without investment..

\section{ACKNOWLEDGEMENT}

We would like to thanks Normasturah Abd Manan and Nadirah Aziz for their efforts in collecting the secondary data through Bursa Malaysia and Universiti Tenaga Nasional library.

\section{REFERENCES}

Abdullah, W. N., Said, R., \& Caliyurt, K. (2019). The Effect of Internal Governance on Corporate Financial Crime Of Companies in Malaysia. Journal of Governance and Integrity, 2(2), 53-64. https://doi.org/10.15282/jgi.2.2.2019.5468

Abughniem, M. S., Al Aishat, M. A. H. \& Hamdan, A. (2020). Free Cash Flow and Firm Performance: Empirical evidence from the Amman Stock Exchange, International Journal of Innovation, Creativity and Change, Vol. 10, Issue 12, 668-681

Ahmed, E. R., Yousif Alabdullah, T. T., Shaharudin, M. S., \& Putri, E. (2020). Further Evidence on The Link Between Firm's Control Mechanisms and Firm Financial Performance: Sultanate Of Oman. Journal of Governance and Integrity, 4(1), 6-11. https://doi.org/10.15282/jgi.4.1.2020.5607

Antoniadis, I., Lazarides, T., Sarrianidis, N., \& Goupa, H. (2008). The impact of Agency Problem in Firm value and the Greek Stock Exchange Market Financial Crisis. In International Conference on Applied Economics- ICOAE (p. 27).

Bhundia, D. A. (2012). A comparative Study Between Free Cash Flows and Earnings Management. Business Intelligence Journal, Vol.5 No.1, 123-129.

Brush, Thomas H., Philip Bromiley \& MargarethaHendrickx, (2000).The Free Cash Flow Hypothesis for Sales Growth and Firm Performance.Strategic Management Journal, 21, 455-472.

Byrd, J. (2010). Financial Policies and the Agency Costs of Free Cash Flow: Evidence from the Oil Industry. International Review of Accounting, Banking and Finance, Vol. 2 No. 2, pp. 23-50

Choudhary, P. (2021). Agency costs, Board structure and Institutional investors: Case of India. Asian Journal of Accounting Research. https://doi.org/10.1108/AJAR-12-2020-0130.

Gani, A. A. M. O., Al Rahbi, A. H. S. S., \& Ahmed, E. R. (2021). Empirical Analysis on Corporate Transparency, Competitive Advantage, and Performance: An Insight of Muscat Securities Market. Journal of Governance and Integrity, 4(2), 96-102. https://doi.org/10.15282/jgi.4.2.2021.6091

Ghanbari, M., Haidari, F., Nazarzadeh, S. \& Abasi, B. (2015) The Relationship between Cash Flow and Financial Performance of Accepted Companies in the Tehran Stock Exchange, MAGNT Research Report (ISSN. 1444-8939) Vol.3 (2), 1829-1841.

Griffin P., Lont D. \& Sun Y. (2010). Agency Problems and Audit Fees Further Tests of the Free Cash Flow Hypothesis. Accounting \& Finance, Vol. 50, Issue 2, 321-350.

Gul, F. A., \& Tsui, J. S. L. (2012). Free cash flow, debt monitoring, and audit pricing: Further evidence on the role of director equity ownership. Auditing, 20 (2), 71-84.

Hau, L. L. (2017). Free Cash Flow and Firm Performance: Evidence from sectoral level for Vietnams listed firms. International Journal of Advanced Engineering, Management and Science (IJAEMS). Vol. 3, Issue 4, 296-300.

Hwang, L.S., Kim, H., Park, K. \& Park, R.S. (2013). Corporate governance and payout policy: evidence from Korean business groups. Pacific-Basin Finance Journal, Vol. 24 (September), 179-198.

Jayiddin, N. F., Jamil, A., \& Roni, S. M. (2017). Capital structure influence on construction firm performance. In SHS Web of Conferences (Vol. 36, p. 00025)

Jensen, M. C.(1986). Agency Costs of Free Cash Flow, Corporate Finance, and Takeovers. American Economic Review, Vol. 76 No. 2, 323-329

Jensen, M. C. \& Meckling, W. (1976). Theory of the Firm: Managerial Behavior, Agency Costs and Ownership Structure. Journal of Financial Economics, Vol. 3, 305-360.

John, K., Knyazeva, A. and Knyazeva, D. (2015). Governance and payout precommitment. Journal of Corporate Finance, Vol.33(August), 101-117.

Kadioglu, E. \& Yilmaz, E.A. (2017). Is the free cash flow hypothesis valid in Turkey. Borsa Istanbul Review, Vol. 17 No. 2, $111-116$.

Kyazze, L. M., Nsereko, I., \& Nkote, I. (2020). Cooperative practices and non-financial performance of savings and credit cooperative societies. International Journal of Ethics and Systems.

Lachheb, A. \& Slim C. (2017). The Impact Of Free Cash Flow and Agency Cost on Firm Performance. Proceedings of ISER 56th International Conference, Rome, Italy, 20th -21st May 2017.

Labhane, N.B. and Mahakud, J. (2016). Determinants of dividend policy of Indian companies: A panel data analysis. Paradigm, Vol. 20 No. 1, 36-55. 
Lang, L.H.P.\& Litzenberger, R.H. (1989).Dividend Announcements: Cash Flow Signaling vs. Free Cash Flow Hypothesis. Journal of Financial Economics, Vol. 24, 181-191.

Lang, L. Stulz, R. \& Walking, R. (1991). A Test of the Free Cash Flow Hypothesis: The Case of Bidder Returns. Journal of Financial Economics, Vol. 29 No. 2, 315-336.

Li, S., Gao, D. „\& Hui, X (2020). Corporate Governance, Agency Costs, and Corporate Sustainable Development: A Mediating Effect Analysis. Hindawi, Discrete Dynamics in Nature and Society,Vol. 2021, Article ID 5558175

Miguny, A., Zinjirdar, M. \& Gesemy, M. (2013). Explain the relationship between agency cost and performance of companies with institutional ownership firms accepted in Tehran Stock Exchange. Indian Journal of Fundamental and Applied Life Sciences, 3(3) $176-179$.

Modigliani F.\& Miller M. (1958). The cost of capital, corporation finance and the theory of investment. American Economic Review, 261-297.

Nobance, H., Ellili, N., \& Abraham, J. (2017). Equity concentration, agency costs and performance of non-financial firms. Global Business Review, 18(1):1-9

Nuhu, B. A., Dandago, K. I., Mohammad, L., Ado, A. B. \& Abdulkarim, U. F. (2020). Impact of Agency Costs on Financial Performance of Listed Consumer Goods Companies in Nigeria, Journal of Management and Theory Practice, Vol.1, Issue 3, $51-55$

Omonov, A., Vasiev, A., Maksudov, B. Abdunazarov, S. \& Sherkhadjaev. A. (2021). Correlation and regression analysis of factors influencing the profitability of commercial banks in Uzbekistan. Turkish Online Journal of Qualitative Inquiry, Vol. 12, No. 7, 4659-4667.

Pahii, D. \& Yadav, I.S. (2021). Product market competition, agency cost and dividend payouts: new evidence from emerging market. Journal of Management and Governance, https://doi.org/10.1007/s10997-021-09570-0

Sapuan, N. M., Abdul Wahab, N., Sholihin, M., \& Sawaluddin, S. (2020). Human Governance and Firm Success From Western and Islamic Perspectives. Journal of Governance and Integrity, 4(1), 56-63. https://doi.org/10.15282/jgi.4.1.2020.5685

Sapuan, N. M. \& Mohd Zeni, N. A. (2021). The Determinants of Waqf Sustainability in Malaysia: A PLS-SEM Analysis. International Journal of Business and Society, 22(1), 102-118. https://doi.org/10.33736/ijbs.3164.2021

Sitthipongpanich T., (2017). Family ownership and free cash flow. International Journal of Managerial Finance, Vol. 13 Issue: 2 , 133-148.

Velnampy, T. \& Kajananthan, R. (2013). Cash Position and Profitability of Telecommunication Sector in Sri Lanka. Greener Journal of Social Sciences, Vol. 3 (6), 324 - 333.

Wambua, P. (2013). Effects of agency costs on financial performance of companies listed at the Nairobi Security Exchange. International Journal of Economics and Finance, 1 (5):587-607

Wang, G. Y. (2010). the impacts of free cash flow and agency costs on firm performance. Journal Service Science and Management, 408-418. doi: 10.4236/jssm.2010.34047

Wen, R. (2017). Free Cash Flow, CEO Ability and Firm Performance. Available at SSRN: https://ssrn.com/abstract=2957340 or http://dx.doi.org/10.2139/ssrn.2957340

Wong, F. S., Ganesan, Y., Pitchay, A. A., Haron, H., \& Hendayani, R. (2019). Corporate Governance And Business Performance: The Moderating Role Of External Audit Quality. Journal of Governance and Integrity, 2(2), 34-44. https://doi.org/10.15282/jgi.2.2.2019.5466

Wu, L. (2014). The Impact of Ownership Structure on Debt Financing of Japanese Firms with the Agency Cost of Free Cash Flow. EFMA 2004 Basel Meetings Paper.

\section{AUTHORS' BIOGRAPHY}

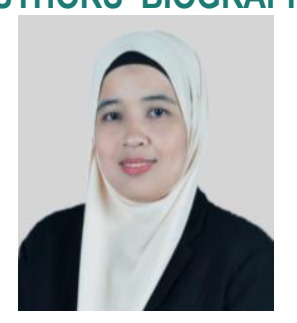

Author's Full Name: Noraina Mazuin Sapuan

Author's Email: noraina@ump.edu.my

Author Professional Bio:

Dr. Noraina Mazuin Sapuan is currently is the Head of Technical and a Senior Lecturer in Faculty of Industrial Management, University Malaysia Pahang, Malaysia. She graduated with Doctor of Philosophy (Economics) from Universiti Malaysia Terengganu (UMT). She completed her undergraduate and Master degree at Universiti Kebangsaan Malaysia (UKM) majoring in Applied Economics and Public Policy and Islamic Economics, respectively. Her research areas are in Applied Macroeconometrics, Financial Economics, Circular Economy - Sustainable Development Goals (Micro / Macro), Environmental Economics, Islamic Banking and Finance and Personal Financial Planning. 


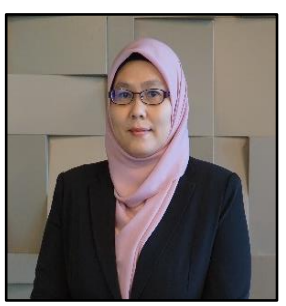

Author's Full Name: Norwazli Bt Abdul Wahab

Author's Email: norwazli@ump.edu.my

Author Professional Bio:

Norwazli Bt Abdul Wahab is currently a Senior Lecturer at Faculty of Industrial Management, Universiti Malaysia Pahang (UMP). She obtained her PhD from Universiti Teknologi MARA (UiTM). She completed her Master of Business Administration in Finance, Bachelor of Accountancy (Hons) and Diploma in Accountancy from Universiti Teknologi MARA (UiTM). She has experience working in the industry as an account and finance executive. Her areas of research include corporate governance, corporate social responsibility, corporate financial performance, financial planning and risk management.

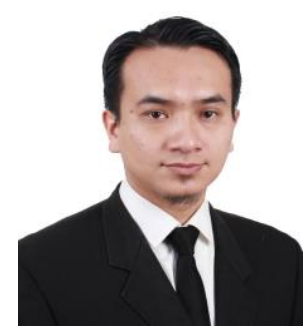

Author's Full Name: Muhammad Ashraf Fauzi

Author's Email: ashrafauzi@ump.edu.my

Author Professional Bio:

Muhammad Ashraf Fauzi is a senior lecturer at the Faculty of Industrial Management, University Malaysia Pahang. He completed his $\mathrm{PhD}$ in the faculty of Management, Multimedia University. He received his bachelor degree in Manufacturing Engineering from International Islamic University Malaysia. He later received a master degree in Manufacturing System Engineering from University Putra Malaysia. His research interests include knowledge management, sustainable building, quality management, project management and sustainable energy.

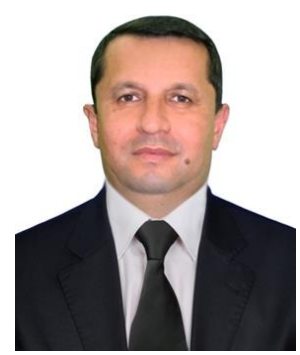

Author's Full Name: Aktom Omonov

Author's Email: akromomonov66@gmail.com

Author Professional Bio:

Aktom Omonov currently is Chair of the Department "Banking" Tashkent Institute of Finance. Specialized in Banking and Finance. The research area is in banking and finance and teaches in those fields at the universities. Worked approximately in a decade for the Central Bank of the Republic of Uzbekistan. 